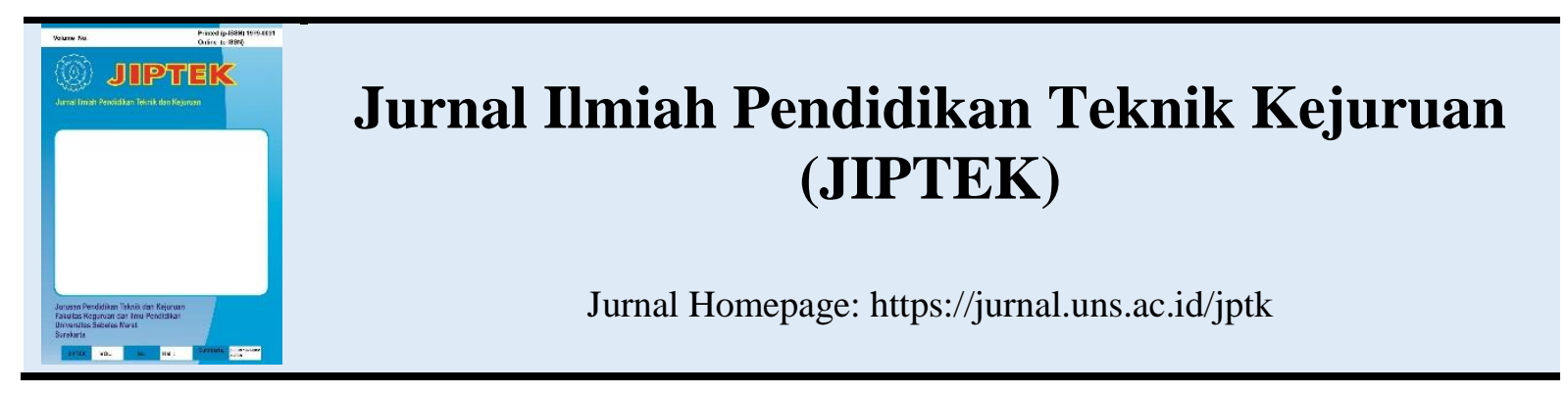

\title{
PERBANDINGAN NILAI HEAT TRANSFER PADA PENAMBAHAN MATERIAL COMPOSIT BATU BATA SEBAGAI UPAYA EFISIENSI ENERGY BANGUNAN GEDUNG
}

\author{
Budi Siswanto \\ Pendidikan Teknik Bangunan, Fakultas Keguruan dan Ilmu Pendidikan \\ Universitas Sebelas Maret \\ email: budisys2@gmail.com
}

\begin{abstract}
Abstrak
Tujuan penelitian ini adalah untuk mengetahui: (1) perbandingan penggantian sebagian tanah liat oleh fly ash, abu sekam padi dan abu jerami padi dilihat dari nilai berat jenis, susut bakar, kuat tekan, porositas dan conductivity batu bata komposit; (2) persentase optimal penggantian sebagian tanah liat oleh fly ash, abu sekam padi dan abu jerami padi dilihat dari nilai berat jenis, susut bakar, kuat tekan, porositas dan conductivity batu bata komposit untuk mendapatkan batu bata dengan daya hambat panas maksimal. Penelitian ini merupakan penelitian kuantitatif dengan menggunakan metode eksperimen. Karakteristik batu bata yang diuji pada penelitian ini adalah berat jenis, susut bakar, porositas, kuat tekan, dan konduktivitas termal. Benda uji yang digunakan terbuat dari tanah liat dengan campuran fly ash, abu sekam padi dan abu jerami padi dengan dimensi $23 \mathrm{~cm}$ x $11 \mathrm{~cm}$ x $5 \mathrm{~cm}$. Hasil penelitian adalah sebagai berikut ini. Pertama, ada pengaruh penggantian sebagian tanah liat terhadap nilai thermal conductivity ( $\mathrm{F}_{\text {hitung }}$ 57,927 > $\mathrm{F}_{\text {tabel }}$ 4,67). Kedua, Persentase 50\% merupakan persentase optimal penggantian sebagian tanah liat dengan daya hambat panas sebesar 0,201 $\mathrm{Kcal} / \mathrm{mh}^{\circ} \mathrm{C}$.
\end{abstract}

Kata kunci: batu bata, fly ash, abu sekam padi, abu jerami padi, konduktivitas termal

\section{Pendahuluan}

Pemanasan global atau global warming adalah suatu bentuk ketidakseimbangan ekosistem di bumi akibat terjadinya proses peningkatan suhu rata-rata atmosfer, laut, dan daratan di bumi. Pemanasan global sendiri merupakan fenomena peningkatan temperatur global dari tahun ke tahun karena terjadinya efek rumah kaca atau greenhouse effect yang disebabkan oleh meningkatnya emisi gas-gas seperti karbondioksida $(\mathrm{CO} 2)$, metana $(\mathrm{CH} 4)$, dinitroksida (N2O), dan $\mathrm{CFC}$ sehingga sinar matahari terperangkap dalam atmosfer bumi.

Salah satu efek dari adanya pemanasan global yang dapat kita rasakan saat ini adalah tingginya temperatur yang terjadi pada ruang dalam bangunan. Tingginya temperatur pada siang hari, dan temperatur tersebut masih relatif tinggi pada malam hari, meskipun pada saat itu temperatur udara luar relatif rendah. Sehingga ruang menjadi tidak nyaman untuk digunakan.

Dalam usaha memperoleh kenyamanan termal, banyak orang yang menggunakan Air Conditioner (AC) untuk mendinginkan udara suatu ruangan. Penggunaan AC dilakukan karena adanya perpindahan panas dari lingkungan ke ruangan sehingga suhu akhir ruangan mendekati dengan suhu lingkungan. Penggunaan AC perlu mendapat perhatian khusus, karena penggunaan AC mengeluarkan 
biaya operasional listrik yang cukup besar. Selain itu penggunaan AC juga menjadi salah satu faktor penyebab pemanasan global. Penggunaan AC yang mengandung klor (chlor) seperti freon atau CFC (chlorflourcarbon) sangat tidak ramah lingkungan. Zat-zat inilah yang dapat merusak lapisan ozon atmosfir bumi yang berdampak pada pemanasan global.

Batu bata adalah salah satu material pembentuk bangunan, yaitu dinding pembatas. Batu bata yang digunakan sebagai dinding pembatas bagian luar menjadi pelindung pertama bagi manusia sebagai penghuni bangunan dari iklim dan situasi alam di luar bangunan. Pada saat ini batu bata terbilang masih cukup diminati oleh masyarakat Indonesia. Beberapa faktor yang menyebabkan batu bata masih cukup diminati masyarakat antara lain mudah didapat dan banyak diproduksi, dan juga harganya yang murah sehingga dapat dijangkau oleh masyarakat luas terutama bagi mereka yang berpenghasilan menengah ke bawah.

Pada masa kini kebutuhan dinding bangunan dengan batu bata yang masih menjadi favorit menyebabkan perlu diusahakan bahan alternatif dalam campuran pembuatan material batu bata. Telah banyak penelitian yang dilakukan mengenai pemanfaatan beberapa limbah industri untuk penambahan dalam campuran berbagai keperluan bahan bangunan. Salah satunya dengan pemanfaatan limbah fly ash, abu sekam padi dan abu jerami padi. Fly ash merupakan limbah padat yang dihasilkan dari pembakaran batubara. Limbah padat ini terdapat dalam jumlah yang cukup besar. Jumlah tersebut yang cukup besar, sehingga memerlukan pengelolaan agar tidak menimbulkan masalah lingkungan, seperti pencemaran udara, perairan, dan penurunan kualitas ekosistem (Kusdiyono \& Rochadi, 2012: 98).

Bahan ini potensinya ternyata cukup melimpah dan belum termanfaatkan dengan baik. Semakin meningkatnya pemakaian batubara, maka beban lingkungan juga akan semakin berat dan perlu diantisipasi dengan pemakaian teknologi batubara bersih dan pemanfaatan secara optimal dari limbah batubara tersebut.

Penelitian ini bertujuan untuk mencari nilai thermal properties yang dihasilkan dari batu bata dengan campuran fly ash, abu sekam padi dan abu jerami padi. Dengan mencari nilai thermal properties batu bata dengan campuran fly ash, abu sekam padi dan abu jerami padi, diharapkan mampu memetakan material batu bata sebagai dinding pembatas yang ramah lingkungan dan hemat energi.

\section{Metode Penelitian}

Penelitian dilaksanakan di Laboratorium Pendidikan Teknik Bangunan Universitas Sebelas Maret Surakarta untuk uji bahan dan uji sifat fisis dan mekanis batu bata. Sedangkan pengujian thermal properties dilaksanakan di Laboratorium Pusat Penelitian dan Pengembangan Perumahan dan Permukiman, Cileunyi, Bandung.

Jenis penelitian yang digunakan adalah penelitian kuantitatif yaitu mengambil suatu gambaran mengenai pengaruh penggantian sebagian tanah liat oleh fly ash, abu sekam padi dan abu jerami padi terhadap nilai thermal properties batu bata.

Sampel yang digunakan yaitu benda uji batu bata merah dengan dimensi $23 \mathrm{~cm} \times 11$ $\mathrm{cm} \times 5 \mathrm{~cm}$. Pada tabel berikut akan dijelaskan banyaknya sampel dalam satu varian. Dimana seluruh sampel yang ada merupakan anggota dari populasi.

Tabel 1. Jumlah Sampel

\begin{tabular}{cccc}
\hline Fly Ash & Thermal & Mekanis & Fisis \\
\hline $0 \%$ & 6 & 6 & 12 \\
$15 \%$ & 6 & 6 & 12 \\
$30 \%$ & 6 & 6 & 12 \\
$40 \%$ & 6 & 6 & 12 \\
$50 \%$ & 6 & 6 & 12 \\
\hline Jumlah & 30 & 30 & 60 \\
\hline
\end{tabular}

\section{Uji Thermal Properties}

\section{Konduktivitas Termal}

Pengujian konduktivitas termal dilaksanakan sesuai dengan ASTM-C1771997 menggunakan Thermal Conductivity Meter TC32. Persamaan yang digunakan adalah:

$$
q=-k A \frac{d T}{d L}
$$

Dimana:

$k=$ Konduktivitas termal bahan $\left(\mathrm{Kcal} / \mathrm{mh}^{\circ} \mathrm{C}\right)$

$\frac{d T}{d L}=$ Gradien suhu pada penampang $\left({ }^{\circ} \mathrm{C} /\right.$ meter $)$

$\mathrm{A}=$ Luas penampang yang dialiri panas secara konduksi $\left(\mathrm{m}^{2}\right)$

$q$ = Laju perpindahan kalor (Kcal) 


\section{Densitas}

Pengujian densitas dilakukan cara manual sesuai dengan SNI 15-2094-2000. Persamaan yang digunakan adalah:

$\rho=\frac{m}{v}$

$\rho=$ Berat jenis $\left(\mathrm{gr} / \mathrm{cm}^{3}\right)$

$\mathrm{m}=$ Berat batu bata (gr)

$\mathrm{v}=$ Volume batu bata $\left(\mathrm{cm}^{3}\right)$

\section{Uji Karakteristik Mekanis}

\section{Kuat Tekan}

Pengujian kuat tekan dilaksanakan sesuai SNI 15-2094-2000 dengan menggunakan Gotech Testing Machine U60. Persamaan yang digunakan adalah:

$\sigma=P / A$

Dengan:

$\sigma=$ Tekanan $\left(\mathrm{N} / \mathrm{mm}^{2}\right)$

$P=$ Beban maksimum $(\mathrm{N})$

$A=$ Luas bidang permukaan $\left(\mathrm{mm}^{2}\right)$

\section{Uji Karakteristik Fisis}

\section{Porositas}

Pengujian porositas dilaksanakan sesuai

SNI 15-2094-2000. Persamaan yang digunakan adalah:

$\operatorname{Porositas}(\%)=\frac{M b-M k}{V b} \times \frac{1}{\rho} \times 100 \%$

Dengan:

$\mathrm{Mb}=$ Massa kering benda uji (gr), setelah direndam dalam air 2x24 jam (gr)

Mk = Massa basah benda uji (gr)

$\mathrm{Vb}=$ Volume benda uji $\left(\mathrm{cm}^{3}\right)$

$\rho$ air $=$ Massa jenis air $\left(\mathrm{gr} / \mathrm{cm}^{3}\right)$

\section{Susut Bakar}

Pengujian susut bakar dilakukan sesuai SNI 15-2094-2000 dengan cara manual yaitu dengan membandingkan panjang sampel batu bata sebelum dan sesudah dibakar. Persamaan yang digunakan adalah:

Susut Bakar $(\%)=\frac{l o-l i}{l o} \times 100 \%$

Dengan:

$l o \quad=$ Panjang sampel benda uji sebelum dibakar $(\mathrm{cm})$

$l i \quad=$ Panjang sampel benda uji sesudah dibakar $(\mathrm{cm})$

Pengolahan data lanjutan digunakan analisis regresi, yaitu untuk mengetahui berapa besar pengaruh penggantian sebagian tanah liat oleh fly ash, abu sekam padi dan abu jerami padi terhadap thermal properties batu bata.Sebelum dilakukan analisis regresi, beberapa prasyarat analisis yang harus dipenuhi adalah pengujian normalitas untuk mengetahui distribusi data, dan uji linearitas untuk mengetahui linear atau tidaknya data pada variabel terikat, analisis regresi untuk mengetahui berapa besar pengaruh penggantian sebagian tanah liat oleh fly ash, abu sekam padi dan abu jerami padi terhadap thermal properties batu bata.

\section{Hasil Penelitian dan Pembahasan}

\section{Pengujian Konduktivitas Termal}

Material konduktivitas rendah mempunyai daya isolator yang baik. Sebaliknya material yang mempunyai nilai konduktivitas tinggi merupakan material penghantar panas yang baik (Rosenlund, 2000 dalam Noerwarsito dan Santosa 2006, 148).

Dengan menggunakan Thermal Conductivity Meter TC-32 diperoleh data konduktivitas termal yang dapat dilihat pada tabel di bawah ini:

Tabel 2. Pengujian Konduktivitas Termal

\begin{tabular}{|c|c|}
\hline $\begin{array}{c}\text { Persentase } \\
\text { Fly Ash }\end{array}$ & $\begin{array}{c}\text { Konduktivitas Termal } \\
\text { Rata-Rata } \\
\left(\mathrm{Kcal} / \mathrm{mh}^{\circ} \mathrm{C}\right)\end{array}$ \\
\hline $0 \%$ & 0,362 \\
\hline $15 \%$ & 0,264 \\
\hline $30 \%$ & 0,282 \\
\hline $40 \%$ & 0,215 \\
\hline $50 \%$ & 0,201 \\
\hline
\end{tabular}

Dari tabel di atas dapat dilihat hubungan konduktivitas termal batu bata dan persentase penggantian fly ash, abu sekam padi dan abu jerami padi dapat dilihat bahwa persentase penggantian sebagian tanah liat oleh fly ash, abu sekam padi dan abu jerami padi dari variasi $0 \%$ sampai $15 \%$ mengalami penurunan, tetapi pada persentase $30 \%$ mengalami kenaikan konduktivitas termal, kemudian pada variasi $40 \%$ sampai $50 \%$ kembali mengalami penurunan konduktivitas termal.

Densitas

Berikut ini merupakan hasil dari pengujian densitas batu bata: 
Tabel 3. Pengujian Densitas

\begin{tabular}{cc}
\hline $\begin{array}{c}\text { Persentase } \\
\text { Fly Ash }\end{array}$ & Densitas $\left(\mathrm{gr} / \mathrm{cm}^{3}\right)$ \\
\hline $0 \%$ & 1,35 \\
$15 \%$ & 1,18 \\
$30 \%$ & 1,14 \\
$40 \%$ & 1,02 \\
$50 \%$ & 0,98 \\
\hline
\end{tabular}

Berdasarkan tabel di atas, terlihat densitas semakin turun seiring dengan bertambahnya jumlah fly ash dalam batu bata.

\section{Kuat Tekan}

Dengan menggunakan Gotech Testing Machine U60 diperoleh data kuat tekan yang dapat dilihat pada tabel di bawah ini:

Tabel 4. Pengujian Kuat Tekan

\begin{tabular}{cc}
\hline $\begin{array}{c}\text { Persentase } \\
\text { Fly Ash }\end{array}$ & Kuat Tekan $\left(\mathrm{N} / \mathrm{mm}^{2}\right)$ \\
\hline $0 \%$ & 10,60 \\
$15 \%$ & 5,59 \\
$30 \%$ & 3,74 \\
$40 \%$ & 2,37 \\
$50 \%$ & 1,47 \\
\hline
\end{tabular}

Dari tabel di atas terlihat bahwa kuat tekan batu bata terus mengalami penurunan seiring dengan bertambahnya jumlah fly ash, abu sekam padi dan abu jerami padi. Pada persentase penggantian fly ash, abu sekam padi dan abu jerami padi $40 \%$ - 50\% batu bata tidak masuk dalam dalam kuat tekan minimal yang disyaratka oleh SNI 15-2094-2000 dengan kuat tekan masing-masing yang dihasilkan sebesar 2,37 N/mm ${ }^{2}$ dan 1,47 $\mathrm{N} / \mathrm{mm}^{2}$.

\section{Porositas}

Berikut ini merupakan data hasil dari pengujian porositas batu bata:

Tabel 5. Pengujian Porositas

\begin{tabular}{cl}
\hline $\begin{array}{c}\text { Persentase } \\
\text { Fly Ash }\end{array}$ & $\begin{array}{l}\text { Porositas } \\
(\%)\end{array}$ \\
\hline $0 \%$ & 39,59 \\
$15 \%$ & 38,86 \\
$30 \%$ & 42,83 \\
$40 \%$ & 49,33 \\
$50 \%$ & 48,29 \\
\hline
\end{tabular}

Pada persentase $0 \%$, dan $15 \%$ terjadi penurunan porositas, akan tetapi pada persentase $30 \%$, dan $40 \%$ terjadi peningkatan yang cukup tinggi, dan pada persentase 50\% terjadi penurunan porositas kembali.

Dari penelitian kelima persentase penggantian fly ash, abu sekam padi dan abu jerami padi, porositas batu bata mencapai lebih dari 20\%. Dapat disimpulkan bahwa porositas dari batu bata tidak masuk dalam standar SNI 15-2094-2000.

\section{Susut Bakar}

Dengan membandingkan dimensi batu bata sebelum dibakar dan setelah batu bata dibakar diperoleh data susut bakar yang dapat dilihat pada tabel di bawah ini:

Tabel 6. Pengujian Susut Bakar

\begin{tabular}{cc}
\hline $\begin{array}{c}\text { Persentase } \\
\text { Fly Ash }\end{array}$ & $\begin{array}{c}\text { Susut bakar } \\
(\%)\end{array}$ \\
\hline $0 \%$ & 0,87 \\
$15 \%$ & 0,86 \\
$30 \%$ & 0,67 \\
$40 \%$ & 0,85 \\
$50 \%$ & 1,18 \\
\hline \multicolumn{2}{c}{ Dari tabel di atas terlihat pada } \\
persentase penggantian fly ash, abu sekam \\
padi dan abu jerami padi 0\% - 30\% batu bata \\
mengalami penurunan penyusutan, setelah itu \\
batu bata mengalami kenaikan penyusutan \\
pada persentase 40\% - 50\%.
\end{tabular}

Pembahasan

\section{Konduktivitas Termal}

Hubungan Konduktivitas Termal Batu Bata dan Persentase Penggantian Fly ash, abu sekam padi dan abu jerami padi dapat dilihat pada Gambar 1 bahwa persentase penggantian sebagian tanah liat oleh fly ash, abu sekam padi dan abu jerami padi dari variasi $0 \%$ sampai $15 \%$ mengalami penurunan, tetapi pada persentase $30 \%$ mengalami kenaikan konduktivitas termal, kemudian pada variasi $40 \%$ sampai $50 \%$ kembali mengalami penurunan konduktivitas termal.

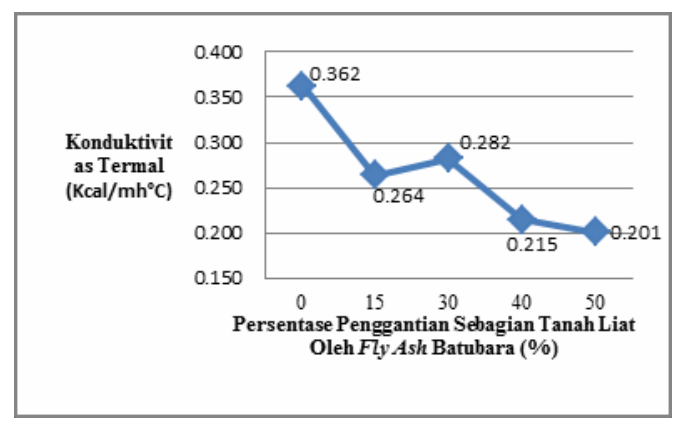


Gambar 1. Hubungan Konduktivitas Termal dan Persentase Penggantian Sebagian Tanah Liat Oleh Fly ash, abu sekam padi dan abu jerami padi

Fly ash, abu sekam padi dan abu jerami padi berpengaruh terhadap nilai konduktivitas termal dikarenakan fly ash, abu sekam padi dan abu jerami padi mempengaruhi banyaknya rongga udara dalam material batu bata. Hal ini erat hubungannya dengan porositas batu bata. Porositas terjadi akibat daya ikat yang sedikit pada tanah liat, semakin sedikit daya ikatnya maka semakin banyak rongga- rongga yang terdapat pada batu bata tersebut. Besar kecilnya daya ikat dipengaruhi oleh berat jenis. Berat jenis tanah liat yang telah dilakukan uji bahan sebelumnya sebesar $2,35 \mathrm{gr} / \mathrm{cm}^{3}$. Sedangakan menurut Clarke (1992) dalam Kilang (2012: 88), menuliskan berat jenis fly ash, abu sekam padi dan abu jerami padi adalah sebesar 1,90 - 2,7 $\mathrm{mg} / \mathrm{cm}^{3}$. Ketika fly ash, abu sekam padi dan $a b u$ jerami padi tersebut dicampurkan ke dalam adukan tanah liat, fly ash menggantikan volume dari tanah liat, dapat dipastikan berat jenis tanah liat akan digantikan dengan berat jenis fly ash, abu sekam padi dan abu jerami padi. Itulah mengapa ketika sebagian volume dari tanah liat dalam batu bata digantikan dengan fly ash maka akan mengurangi berat jenis batu bata itu sendiri. Semakin tinggi kerapatan spesimen, maka semakin cepat perpindahan kalor yang terjadi. Sebaliknya semakin rendah kerapatan spesimen, maka semakin lambat perpindahan kalor yang terjadi. Dengan demikian persentase penggantian sebagian tanah liat oleh fly ash, abu sekam padi dan abu jerami padi 50\% dengan nilai konduktivitas termal sebesar 0,201 $\mathrm{Kcal} / \mathrm{mh}^{\circ} \mathrm{C}$ merupakan persentase yang paling baik dalam menghambat panas.

Mengingat bahwa batu bata adalah bahan penyusun dinding, selain memperhatikan nilai hambat panas juga harus memperhatikan persyaratan fisis dan mekanis yang terdapat pada SNI 15-20942000 diantaranya adalah porositas dan kuat tekan. Dari hasil penelitian bahwa kuat tekan pada persentase penggantian sebagian tanah liat oleh fly ash, abu sekam padi dan abu jerami padi $40 \%$ - 50\% tidak masuk dalam standar minimum SNI sehingga batu bata tidak bisa digunakan sebagai bahan penyusun dinding. Dengan demikian persentase penggantian fly ash, abu sekam padi dan abu jerami padi $15 \%$ merupakan persentase terbaik dengan nilai kuat tekan sebesar $5,59 \mathrm{~N} / \mathrm{mm}^{2}$ dan nilai konduktivitas termal sebesar $0,264 \mathrm{Kcal} / \mathrm{mh}^{\circ} \mathrm{C}$.

\section{Densitas}

Dalam penelitian ini, dengan penggantian sebagian tanah liat oleh fly ash, abu sekam padi dan abu jerami padi menjadikan batu bata menjadi lebih ringan karena densitas batu bata yang didapatkan berkisar antara $0,98-1,35 \mathrm{gr} / \mathrm{cm}^{3}$.

Berikut ini merupakan grafik hasil pengujian densitas:

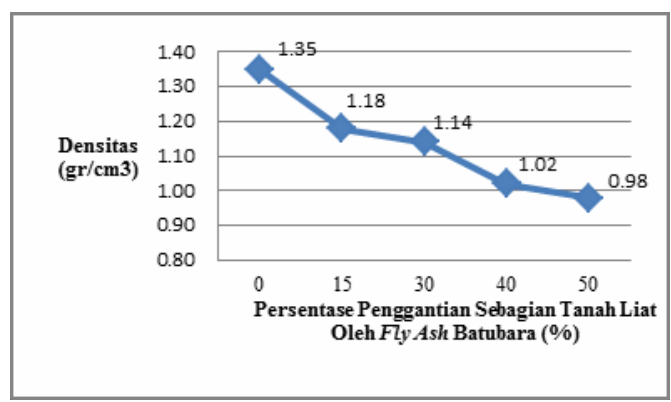

Gambar 2. Hubungan Densitas dan Persentase Penggantian Sebagian Tanah Liat Oleh Fly ash, abu sekam padi dan abu jerami padi

Ganbar 2 menunjukkan hubungan antara densitas dan persentase penggantian fly ash, abu sekam padi dan abu jerami padi, terlihat densitas semakin turun seiring dengan bertambahnya jumlah fly ash dalam batu bata. Hal ini disebabkan antara berat jenis tanah liat dan fly ash, abu sekam padi dan abu jerami padi yang berbeda. Berat jenis tanah liat yang telah melalui uji bahan sebelumnya sebesar $2,35 \mathrm{gr} / \mathrm{cm}^{3}$. Sedangakan menurut Clarke (1992) dalam Kilang (2012: 88), menuliskan berat jenis fly ash, abu sekam padi dan abu jerami padi adalah sebesar $1,90-2,7 \mathrm{mg} / \mathrm{cm}^{3}$. Ketika fly ash, abu sekam padi dan abu jerami padi tersebut dicampurkan ke dalam adukan tanah liat, fly ash menggantikan volume dari tanah liat, dapat dipastikan berat jenis tanah liat akan digantikan dengan berat jenis fly ash, abu sekam padi dan abu jerami padi. Itulah mengapa ketika sebagian volume dari tanah liat dalam batu bata digantikan dengan fly ash maka akan mengurangi densitas batu bata itu sendiri.

Densitas memegang peranan yang besar untuk thermal properties, material yang 
mempunyai densitas yang ringan mempunyai daya isolasi lebih besar daripada material yangberdensitas besar.

\section{Kuat Tekan}

Berikut ini merupakan grafik hasil pengujian kuat tekan batu bata:

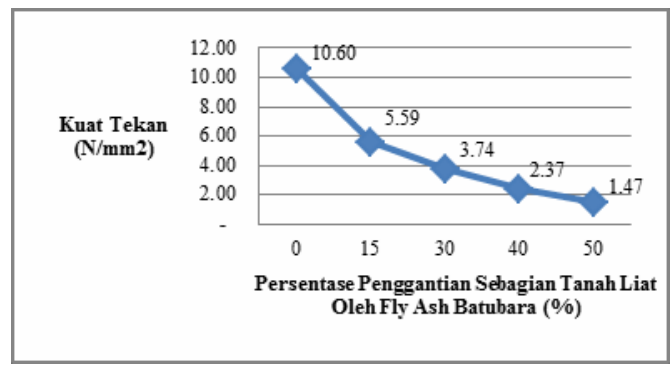

Gambar 3. Hubungan Kuat Tekan dan Persentase Penggantian Sebagian Tanah Liat Oleh Fly ash, abu sekam padi dan abu jerami padi

Dari grafik diatas terlihat bahwa kuat tekan batu bata terus mengalami penurunan. Hal tersebut dikarenakan penggantian fly ash, abu sekam padi dan abu jerami padi semakin banyak, menyebabkan ketidakseimbangan bahan penyusun batu bata. Sehingga menyebabkan ikatan antar bahan penyusun semakin renggang dan porositas semakin besar. Porositas yang besar akan mengakibatkan kuat tekan semakin kecil.

Pada variasi persentase penggantian fly ash, abu sekam padi dan abu jerami padi $0 \%$ kuat tekan sebesar 10,60 N/mm ${ }^{2}$ masuk dalam mutu batu bata 100 , pada variasi $15 \%$ kuat tekan sebesar 5,59 N/mm ${ }^{2}$ masuk dalam mutu 50, dan variasi $30 \%$ kuat tekan sebesar 3,74 masuk dalam mutu 25. Dari variasi persentase penggantian fly ash, abu sekam padi dan abu jerami padi $0 \%$ - 30\% masuk dalam standar minimal kuat tekan batu bata yang disyaratkan oleh SNI 15- 2094-2000. Sedangan pada variasi $40 \%$ dan $50 \%$ batu bata tidak masuk dalam kuat tekan minimal yang disyaratkan oleh SNI 15-2094-2000 dengan masingmasing kuat tekan yang dihasilkan sebesar $2,37 \mathrm{~N} / \mathrm{mm}^{2}$ dan $1,47 \mathrm{~N} / \mathrm{mm}^{2}$.

\section{Porositas}

Berikut ini merupakan grafik hasil pengujian porositas batu bata:



Gambar 4. Hubungan Porositas dan Persentase Penggantian Sebagian Tanah Liat Oleh Fly ash, abu sekam padi dan abu jerami padi

Menurut SNI 15-2094-2000 porositas batu bata tidak boleh melebihi 20\%. Dari penelitian kelima persentase penggantian fly ash, abu sekam padi dan abu jerami padi, porositas batu bata mencapai lebih dari $20 \%$. Dapat disimpulkan bahwa porositas dari batu bata tidak masuk dalam standar SNI 15-20942000.

Pada persentase $0 \%$, dan $15 \%$ terjadi penurunan porositas, akan tetapi pada persentase $30 \%$, dan $40 \%$ terjadi peningkatan yang cukup tinggi, dan pada persentase $50 \%$ terjadi penurunan porositas kembali.

Menurut analisis, penambahan air ketika proses pencampuran antara tanah liat dan fly ash sangat berperan penting. Yang terjadi di lapangan adalah tidak adanya takaran khusus yang dijadikan acuan dalam proses pencampuran. Penambahan air terus dilakukan sampai tanah liat dan fly ash dirasa cukup homogen untuk dilakukan pengadukan.

Ketika proses pengeringan dan pembakaran, air yang terkandung dalam batu bata mengalami penguapan, sehingga mengakibatkan terjadinya rongga-rongga pada batu bata. Meskipun partikel fly ash dam tanah liat akan merapat dan mengisi rongga tersebut, namun karena terlalu banyaknya air, ikatan partikel fly ash dan tanah liat tidak sempurna.

Dengan nilai porositas yang melebihi $20 \%$, hal yang perlu diperhatikan ketika batu bata tetap digunakan dalam material penyusun dinding adalah proses finishing, yaitu pada saat plester dan pengecatan sehingga dinding tidak mengalami rembesan ketika musim hujan.

\section{Susut Bakar}

Berikut ini merupakan grafik hasil pengujian susut bakar batu bata: 


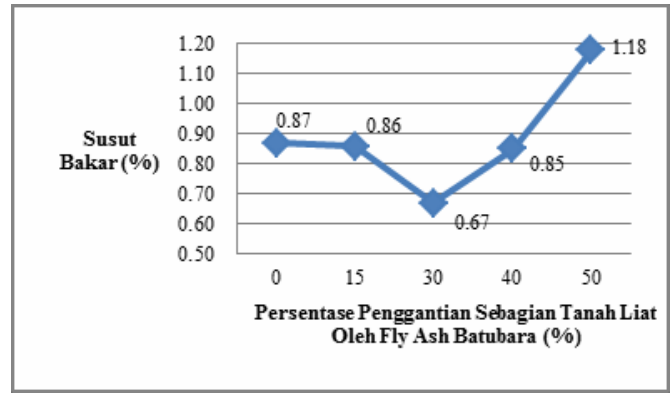

Gambar 5. Hubungan Susut Bakar dan Persentase Penggantian Sebagian Tanah Liat Oleh Fly ash, abu sekam padi dan abu jerami padi

Pemakaian fly ash pada variasi yang berbeda akan mengurangi penyusutan batu bata pada penyusutan kering dan penyusutan bakar terhadap batu bata tanpa fly ash. Namun hal ini hanya mencapai pada persentase campuran fly ash 30\% saja, setelah $40 \%$ dan $50 \%$ terjadi kenaikan penyusutan. Pada persentase fly ash 15\% dan 30\% terjadi penurunan penyusutan, hal ini disebabkan adanya butiran abu terbang yang tidak menyerap air dan butiran abu terbang yang kasar dibandingkan dengan lempung tanpa abu terbang yang berpengaruh terhadap kembang susutnya (Muhardi, 2007 dalam Kilang, 2012: 91). Dari pemeriksaan bahan sebelumnya, tanah liat menunjukkan hasil plastisitas tinggi. Tanah dengan plastisitas tinggi pada umumnya memiliki persentase penyusutan tinggi pula (Daryanto, 1994 dalam Kilang, 2012: 91). Sehingga pada persentase fly ash 15\% dan 30\% dapat menggantikan volume tanah dan mengurangi sifat plastisnya yang terlalu tinggi., maka mampu mengurangi penyusutan. Keadaan berbeda ditunjukkan pada persentase fly ash $40 \%$ dan 50\% justru meningkatkan penyusutan.

\section{Simpulan dan Saran}

Simpulan

Berdasarkan hasil analisis data dan pembahasan dapat diambil simpulan sebagai berikut:

1. Penggantian sebagian tanah liat oleh fly ash, abu sekam padi dan abu jerami padi berpengaruh terhadap nilai thermal properties batu bata yang dibuktikan dari nilai Fhitung 57,927 > Ftabel 4,67. Adapun pengaruhnya tidak signifikan dengan melihat nilai hasil pengujian yang naik turun.
2. Pada penelitian ini batu bata dengan daya hambat panas optimum terdapat pada variasi penggantian fly ash batubara 50\% yaitu sebesar $0,201 \mathrm{Kcal} / \mathrm{mh}^{\circ} \mathrm{C}$.

3. Nilai konduktivitas termal batu bata dengan penggantian fly ash, abu sekam padi dan abu jerami padi pada variasi campuran 0\%, 15\%, 30\%, 40\%, dan 50\% secara berturut-turut adalah sebesar $0,362 \mathrm{Kcal} / \mathrm{mh}^{\circ} \mathrm{C} ; 0,264 \quad \mathrm{Kcal} / \mathrm{mh}^{\circ} \mathrm{C}$; $0,282 \mathrm{Kcal} / \mathrm{mh}^{\circ} \mathrm{C} ; 0,215 \mathrm{Kcal} / \mathrm{mh}^{\circ} \mathrm{C}$; dan $0,201 \mathrm{Kcal} / \mathrm{mh}^{\circ} \mathrm{C}$. Sedangkan nilai densitas secara berturut-turut adalah sebesar $1,35 \mathrm{gr} / \mathrm{cm}^{3} ; 1,18 \mathrm{gr} / \mathrm{cm}^{3} ; 1,14$ $\mathrm{gr} / \mathrm{cm}^{3} ; 1,02 \mathrm{gr} / \mathrm{cm}^{3} ; 0,98 \mathrm{gr} / \mathrm{cm}^{3}$.

4. Melihat dari sifat fisis batu bata (porositas) sebagai parameter kelayakan batu bata sebagai pasangan dinding, dari kelima variasi penggantian sebagian tanah liat oleh fly ash, abu sekam padi dan abu jerami padi nilai porositas tidak masuk dalam standar maksimal porositas yang disyaratkan oleh SNI 15-20942000 yaitu sebesar 20\%. Sedangkan dari sifat mekanis (kuat tekan) persentase $40 \%$ dan $50 \%$ batu bata tidak masuk dalam standar minimal kuat tekan yang disyaratkan oleh SNI 15-2094- 2000.

Dari hasil pengujian persentase $15 \%$ dapat digunakan sebagai pasangan dinding dengan nilai konduktivitas termal sebesar $0,264 \mathrm{Kcal} / \mathrm{mh}^{\circ} \mathrm{C}$, nilai densitas sebesar $1,14 \mathrm{gr} / \mathrm{cm}^{3}$, nilai kuat tekan sebesar $5,59 \mathrm{~N} / \mathrm{mm}^{2}$, dan nilai porositas sebesar 38,86\%. Akan tetapi batu bata disarankan digunakan sebagai dinding dalam dan tidak bisa digunakan sebagai dinding muka, mengingat nilai porositas yang besar. Dengan memperhatikan plesteran dengan baik dan benar, sehingga batu bata ketika digunakan sebagai dinding pembatas tidak mengalami rembesan.

\section{Saran}

Berdasarkan simpulan dan implikasi hasil penelitian, maka dapat dikemukakan saran sebagai berikut:

1. Penelitian lanjutan dengan mengubah posisi batu bata ketika pengujian konduktivitas termal menjadi mendatar.

2. Penelitian lanjutan dengan penggantian tanah liat oleh bottom ash atau dengan limbah yang lainnya. 
3. Penelitian lanjutan perhitungan kalor yang hilang yaitu dengan membandingkan penghematan energi operasional listrik untuk AC antara batu bata biasa dengan batu bata dengan bahan tambah fly ash atau bahan limbah lainnya.

4. Penelitian lanjutan dengan menggunakan cetakan pres dan tungku pembakaran modern agar bentuk batu bata lebih presisi dan panas pembakaran dapat dikontrol dengan mudah.

\section{Daftar Pustaka}

ASTM. (1997). ASTM-C177-1997.Standard Test Method for Steady-State Heat Flux Measurement and Thermal Transmission Properties by Means of the Guarded-Hot- Plate Apparatus. ASTM International: USA

Badan Standarisasi Nasional. (2006). Standar Nasional Indonesia. SNI 15-20942000. Bata Merah Pejal untuk Pasangan Dinding. Dewan Standarisasi Indonesia, Jakarta.

Kilang, C. (2012). Skripsi: Pengaruh Penggantian Tanah Liat Oleh Fly Ash Batu Bara dan Lama Pembakaran Terhadap Karakteristik Fisis dan Mekanis Batu Bata. Universitas Sebelas Maret, Surakarta.

Kusdiyono \& Rochadi. (2012). Jurnal: Pengaruh Pemanfaatan Limbah Batubara (Fly Ash) Terhadap Kekuatan Tekan Mortar Type M. Politeknik Negeri Semarang, Semarang.

Noerwarsito, V.T \& Santosa. (2006). Jurnal: Pengaruh "Thermal Properties" Material Batu Bata dan Batako sebagai Dinding, Terhadap Efisiensi Enerji dalam Ruang di Surabaya. Universitas Kristen Petra, Surabaya. 